\title{
Экологическая безопасность донных отложений Воронежского водохранилища
}

\author{
Н. В. Каверина ${ }^{\bowtie}$, С.А. Куролап \\ Воронежский государственный университет, Российская Федераџия \\ (394018, г. Воронеж, Университетская пл., 1)
}

\begin{abstract}
Аннотация: Цель исследования - экологическая оценка качества донных отложений бассейна p. Воронеж и Воронежского водохранилища в пределах Воронежской городской агломерации.

Mатериаль и методы. Приведены результаты химического анализа состояния донных отложений водохранилища и реки Воронеж (левого притока р. Дон) в зоне прямого воздействия развитого промышленного центра - города Воронеж. Количественный химический анализ загрязняющих веществ в донных отложениях выполнен на базе аттестованной эколого-аналитической лаборатории факультета географии, геоэкологии и туризма Воронежского госуниверситета с применением потенциометрического, титриметрического, вольтамперометрического, гравиметрического и гранулометрического методов анализа.

Результаты и обсуждение. Современное состояние Воронежского водохранилища характеризуется высокой степенью антропогенной нагрузки, обусловленной развитой промышленностью и плотной жилой застройкой. По динамике пространственно-временного накопления загрязняющих веществ в водоеме выделяются зоны с различным уровнем эвтрофикации. Исследованные пробы донного грунта содержат частицы микропластика антропогенного происхождения, негативное воздействие которого на состояние экосистемы водохранилища в значительной степени недооценивается.
\end{abstract}

Ключевые слова: донные отложения, количественный анализ, качественный анализ, кларк концентрации, показатель суммарного загрязнения, приоритетные загрязняющие вещества, микропластик.

Источник финансирования: Исследование выполнено при финансовой поддержке РФФИ, проект № 20-05-00779.

Для цитирования: Каверина Н. В., Куролап С.А. Экологическая безопасность донных отложений Воронежского водохранилища // Вестник Воронежского государственного университета. Серия: География. Геоэкология, 2021, № 2, с. 70-79. DOI: https://doi.org/10.17308/geo.2021.2/3450

\section{ВВЕДЕНИЕ}

Донные отложения, формирующиеся в каждом проточном водоеме, имеют важное диагностическое значение для оценки его экологической безопасности. Если в проточных водотоках русловые осадки формируются в основном из песчаных и глинистых частиц, то донные грунты водохранилищ формируются из илов различного происхождения, включая гумусовый горизонт затопленной почвы.

Концентрация загрязняющих веществ, содержащихся в донных отложениях, создает опасность для биоты и человека. По составу осадков удается отследить историю процессов аккумуляции загрязнителей качества воды прогнозировать возможные изменения качества воды [8]. Известно, что наибольшее токсическое воздействие на гидробионты оказывают микроэлементы и тяжелые металлы. Тем более, что формируется в водных объектах селитебно-промышленных территорий особый вид донных отложений - техногенные илы $[1,5,6]$.

Цель статьи - провести экологическую оценку качественного и количественного состава донных отложений Воронежского водохранилища в границах городской агломерации.

(C) Каверина Н.В., Куролап С.А., 2021

$₫$ Каверина Наталия Викторовна, e-mail: knataliy@mail.ru Контент доступен под лицензией Creative Commons Attribution 4.0 License. 
Для достижения поставленной цели нами были решены две задачи.

1. На материалах Управление Росприроднадзора по Воронежской области [2, 3, 4] и результатах собственных исследований химического [7] и гранулометрического состава донных отложений водохранилища, выполненных в аттестованной эколого-аналитической лаборатории факультета географии, геоэкологии и туризма ВГУ сформировали базу данных концентрации загрязняющих веществ.

2. Для характеристики в донных отложениях тяжелых металлов рассчитали величину их «кларка концентрации» и оценили степень загрязнения техногенных грунтов по показателю суммарного загрязнения (Zc).

\section{МАТЕРИАЛЫ И МЕТОДЫ}

Отбор проб проводился в намеченных точках Воронежского водохранилища в соответствии с ГОСТ 17.1.5.01-80 «Охрана природы. Гидросфера. Общие требования к отбору проб донных отложений водных объектов для анализа на загрязненность».

В августе 2020 года в акватории Воронежского водохранилища и реке Воронеж выше и ниже искусственного водоема было отобрано 9 проб из верхнего донного слоя (10 см глубиной) с применением ковшового дночерпателя Петерсена. Описание мест отбора приведено в таблице 1 и отражено на картосхеме (рис. 1).

Перечень мониторинговых точек отбора донного грунта

[Table 1. List of monitoring points for bottom soil sampling]

Таблииа 1

\begin{tabular}{|c|l|}
\hline $\begin{array}{c}\text { № точки / } \\
\text { Point No. }\end{array}$ & \multicolumn{1}{c|}{ Точки наблюдения / Observation points } \\
\hline 1 & Ниже с. Чертовицы (правый берег р. Воронеж) \\
\hline 2 & Мост трассы М-4 «Дон» (левый берег водохранилища) \\
\hline 3 & Выше ж/д моста в районе ул. Красина (левый берег водохранилища) \\
\hline 4 & Смотровая площадка Северного моста (левый берег водохранилища) \\
\hline 5 & Пристань Чернавского моста (левый берег водохранилища) \\
\hline 6 & Пляж ВОГРЭСовского моста (левый берег водохранилища) \\
\hline 7 & Сброс воды с очистных сооружений (левый берег водохранилища) \\
\hline 8 & В районе сквера Гидроузел (левый берег водохранилища) \\
\hline 9 & Пляж в районе СНТ «Гигиенист» (левый берег р. Воронеж) \\
\hline
\end{tabular}

Физико-химические показатели донных отложений изучались по программе, предусматривающей контроль содержаний тяжелых металлов, нефтепродуктов, водородного показателя и сероводорода, определение гранулометрического (зернового) состава и выделение микропластика.

Сероводород определялся в день отбора проб из влажного образца с последующим пересчетом на сухое вещество. Исследование проводилось по апробированной методике, не включенной в реестр методов, допущенных до государственного аналитического контроля объектов окружающей среды.

Доведенные до воздушно-сухого состояния образцы исследовались на содержание микропластика. Для этого донный грунт помещался в сосуд с добавлением насыщенного раствора хлорида натрия. За счет высокой плотности раствора частицы микропластика различной природы и форм всплывают на поверхность. Отделение от сопутствующих частиц осуществлено с помощью концентрированной перекиси водорода.
Ситовым методом с промывкой в образцах донного грунта определялся гранулометрический (зерновой) состав. Фракции размером 1 мм и меньше исследовались на содержание загрязнителей с использованием стандартных методик (табл. 2).

\section{РЕЗУЛЬТАТЫ И ОБСУЖДЕНИЕ}

Проведенные химико-аналитические исследования позволили установить, что почти в половине проб донного грунта наблюдается преобладание песчаных фракций с размером зерен от 0,25 мм и меньше (46 \%) (рис. 2). Содержание по массе тонкозернистых песчаных (0,1-0,05 мм), алевритовых и глинистых частиц не превышает $2 \%$ от общей массы во всех образцах донного грунта. Таким образом, согласно классификации смешанных пород? образцы донного грунта из водохранилища следует отнести к чистым «пескам».

Толщи донных грунтов водохранилища различаются по цвету горизонтов. Различаются темно-серые, сизые и черные цвета донных от- 


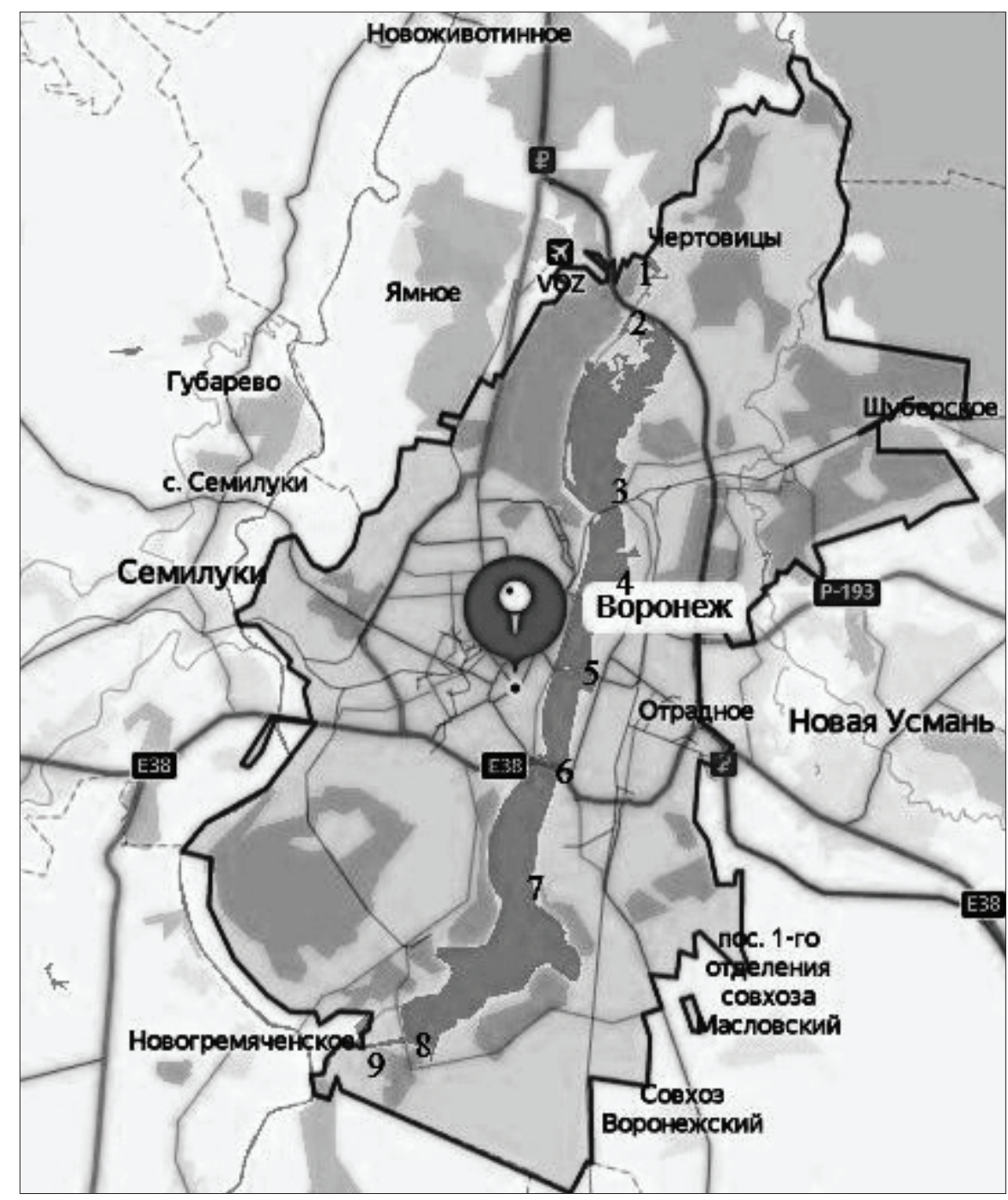

Puc. 1. Карта-схема расположения точек отбора проб

[Fig. 1. Map-scheme of sampling points location]

Методики выполнения химического анализа донных отложений

[Table 2. Methods of performing chemical analysis of bottom sediments]

\begin{tabular}{|c|c|}
\hline $\begin{array}{c}\text { Наименование } \\
\text { показателя / Indicator } \\
\text { name } \\
\end{array}$ & Метод определения / Method of determination \\
\hline $\begin{array}{c}\text { Водородный } \\
\text { показатель }\end{array}$ & $\begin{array}{l}\text { ГОСТ 26423-85 Почвы. Методы определения удельной электрической } \\
\text { проводимости, рН и плотного остатка водной вытяжки }\end{array}$ \\
\hline $\begin{array}{c}\text { Свинец, кадмий, медь, } \\
\text { цинк }\end{array}$ & $\begin{array}{l}\text { ПНД Ф 16.1:2:2.2:3.48-06 Методика выполнения измерений массовой кон- } \\
\text { центрации цинка, кадмия, свинца, меди, марганца, мышьяка и ртути в по- } \\
\text { чвах, тепличных грунтах, сапропелях, илах, донных отложениях, твердых } \\
\text { отходах методом инверсионной вольтамперометрии на анализаторах типа ТА }\end{array}$ \\
\hline Нефтепродукты & $\begin{array}{l}\text { ПНД Ф 16.1.41-04 Количественный химический анализ почв. Методика } \\
\text { выполнения измерений массовой концентрации нефтепродуктов в пробах } \\
\text { почв гравиметрическим методом }\end{array}$ \\
\hline Сероводород & $\begin{array}{l}\text { Санитарно-химический анализ загрязняющих веществ в окружающей } \\
\text { среде. Справочник, М, Химия, 1989, с. } 368\end{array}$ \\
\hline $\begin{array}{l}\text { Зерновой состав грун- } \\
\text { тов }\end{array}$ & $\begin{array}{l}\text { ГОСТ 12536-2014 Грунты. Методы лабораторного определения грануло- } \\
\text { метрического (зернового) и микроагрегатного состава }\end{array}$ \\
\hline
\end{tabular}


ложений, что является признаком оглеения и свидетельствует о наличии восстановительных условий, которые важны при оценке подвижности ряда тяжелых металлов.

Донные отложения водоема - естественное депо для взвешенных веществ и различных химических соединений. Обычно экологическая оценка уровней содержания тяжелых металлов в природных средах осуществляется в соответствии с нормативами качества. Однако для донных отложений не существует утвержденных предельно допустимых концентраций (ПДК). Поэтому содержание тяжелых металлов оценивалось по коэффициенту (кларку концентрации) [8], рассчитанному как отношение содержания химического элемента в образцах донного грунта к кларкам почвы, составленных А.П. Виноградовым в 1962 году.

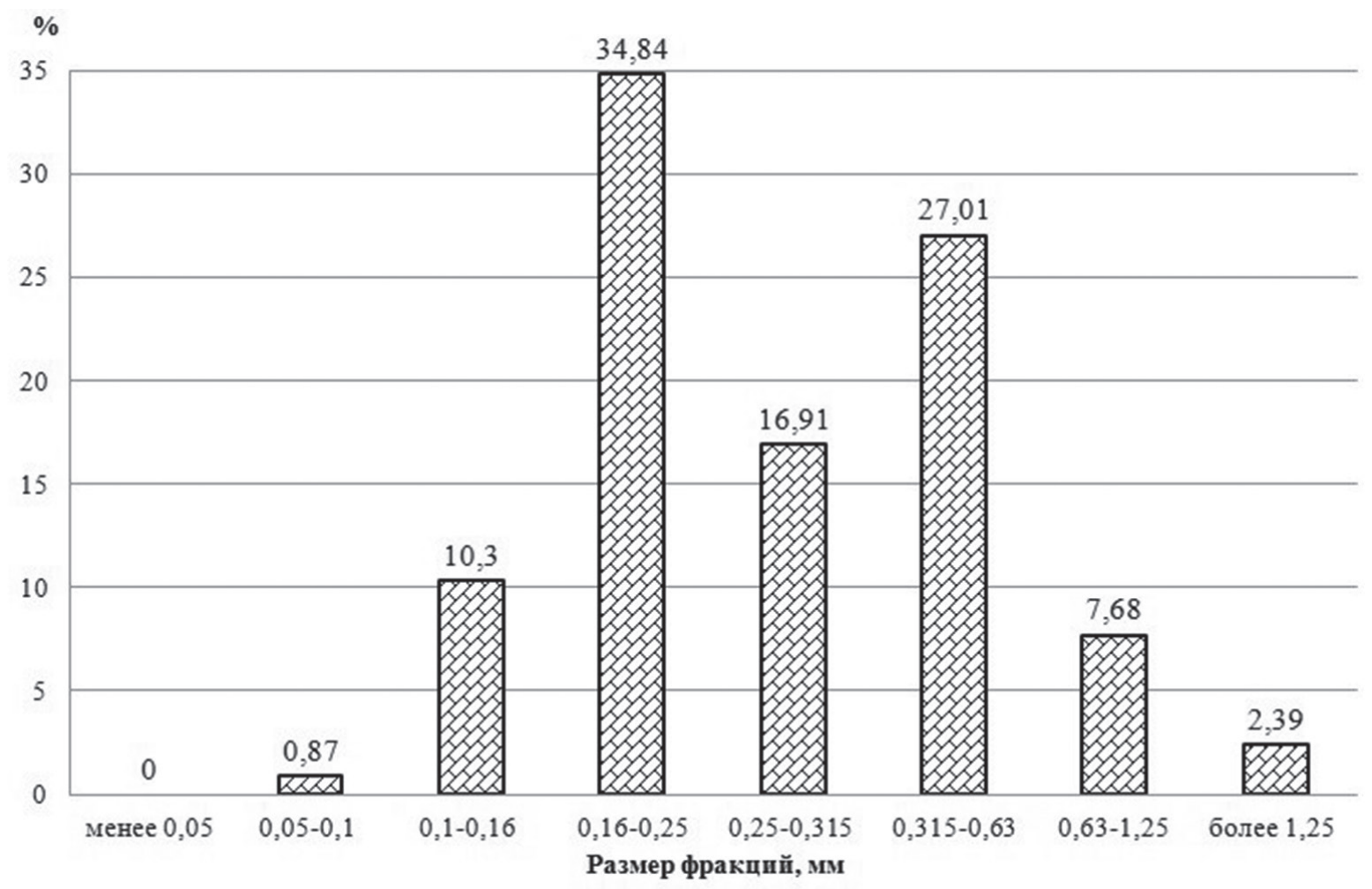

Puс. 2. Усредненный гранулометрический (зерновой) состав донных отложений Воронежского водохранилища [Fig. 2. Average granulometric (grain) composition of bottom sediments in the Voronezh reservoir]

Данные о содержании тяжелых металлов в донном грунте, полученные в период с 2009 по 2020 год на исследуемом участке «р. Воронеж Водохранилище - р. Воронеж», свидетельствуют об относительно низком геохимическом фоне.

Донные отложения верхней части водохранилища и русла реки обеднены металлами и по величине кларков концентрации исследуемые элементы образуют следующий ряд: $\mathrm{Cu}<\mathrm{Zn}<\mathrm{Pb}$ $<\mathrm{Cd}$. Рассеяние элементов обусловлено геохимическими особенностями водосборного бассейна реки, расположенного в пределах Среднерусской возвышенности и Окско-Донской равнины.

Наибольшее рассеяние характерно для меди и цинка. Эти элементы отличаются дефицитным содержанием в течение всего периода наблюдений.

Донные отложения водохранилища на участке от железнодорожного моста и до гидроузла отли- чаются повышенным содержанием кадмия и цинка. В месте сброса стока с левобережных очистных сооружений (точка № 7) нами зафиксированы максимальные кларки концентрации тяжелых металлов: $\mathrm{Zn}<\mathrm{Cu}<\mathrm{Pb}<\mathrm{Cd}$ (рис. 3).

Корреляционный анализ содержания тяжелых металлов и нефтепродуктов показал наличие положительной корреляции в местах воздействия автомобильного и железнодорожного транспорта. Средняя положительная связь между концентрациями нефтепродуктов и кадмием выявлена в точках № 2, 3, 6, 8, 9 (коэффициент корреляции / r / варьирует от 0,68 до 0,55). В точках № 1, 2, 6, 7, 8, 9 установлена средняя и высокая положительная корреляция между содержаниями нефтепродуктов и цинка. Значения коэффициента корреляции изменяется от 0,63 до 0,79 . 


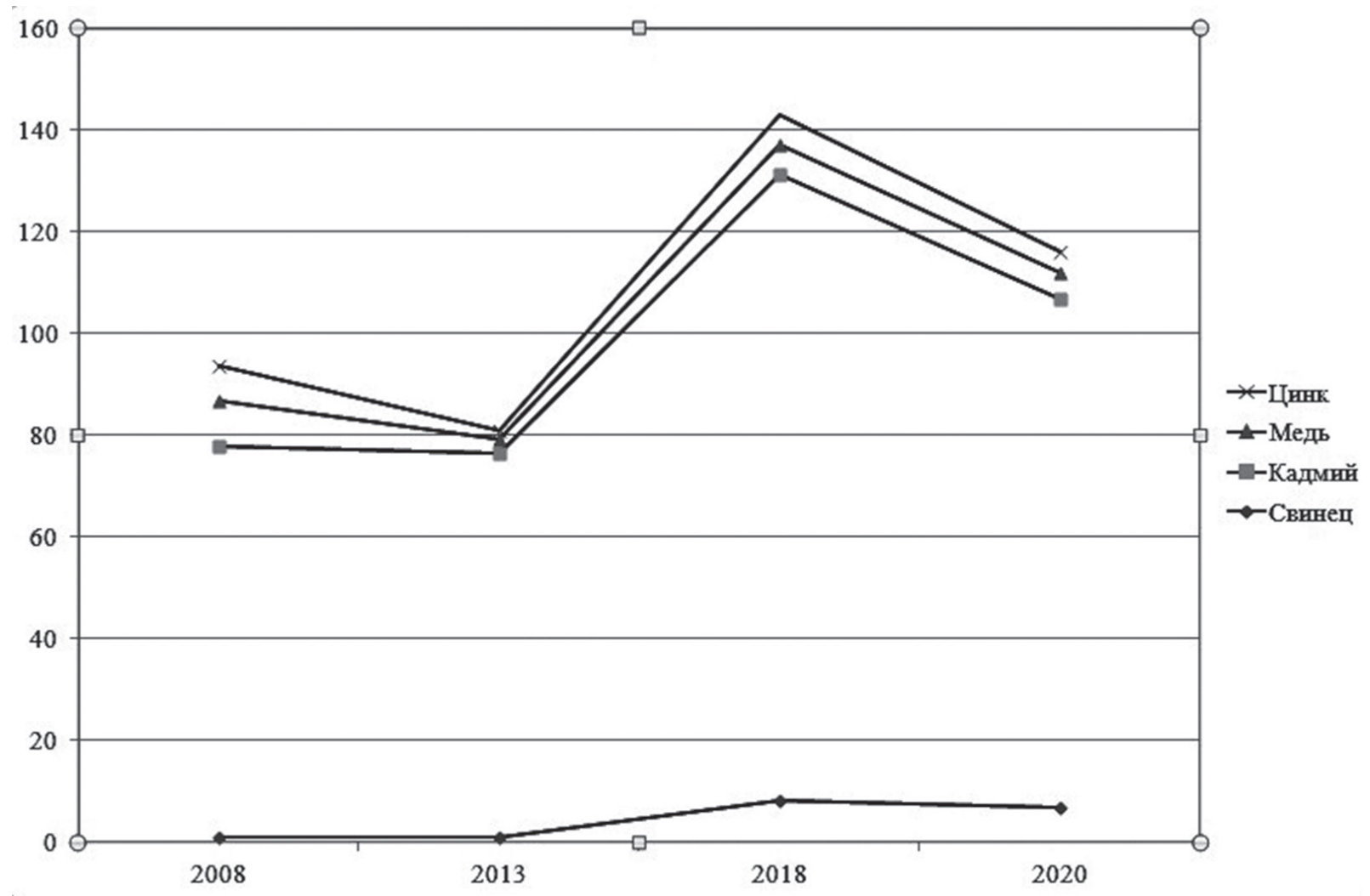

Puc. 3. Кларки концентрации элементов в донных отложениях водохранилища в районе сброса с очистных сооружений

[Fig. 3. The concentration clarks of elements in the bottom sediments of the Voronezh reservoir in the area of discharge from treatment facilities]

На исследуемом объекте выделяется точка № 6 (сбор воды с городских очистных сооружений), в которой все исследуемые компоненты достаточно сильно взаимосвязаны (высокая положительная корреляция).

Среди обязательных показателей, контролируемых в донных отложениях, показателей выделяют сероводород и нефтепродукты. Если об источнике последнего компонента для территории Центрально-Черноземного региона можно с большой долей вероятности говорить о его «техногенном» происхождении, то наличие сероводорода - это реакция водоема на загрязнение воды.

Водохранилище имеет выраженные зоны с различными уровнями содержания сероводорода в донных отложениях. В результате анализа динамики пространственно-временного накопления сероводорода установлено, что выделенные участки совпадают с зонами эвтрофикации водоема. Для участков с «молодыми» отложениями содержание органических веществ значимо и влияет на содержание сероводорода и тяжелых металлов.

За длительный период наблюдения за состоянием водохранилища в 2019 году содержание сероводорода увеличилось практически во всех точках отбора проб по сравнению с предыдущими периодами и достигает максимально высоких значений в местах сброса сточных вод (рис. 4).

В месте сброса стоков с очистных сооружений (точка № 6) в донных отложениях за период с 2008 по 2020 год выявлена высокая положительная корреляция $(\mathrm{r}=0,85)$ между водородным показателем и сероводородом. Можно с уверенностью говорить о едином факторе, влияющим на сильную взаимосвязь этих значений. К нему можно отнести наличие в донном грунте «техногенных» нефтепродуктов. В этих точках корреляции между их содержанием и концентрациями сероводорода составляет: для точки № $6 \mathrm{r}=0,79$ и для точки № $8 \mathrm{r}=0,55$.

Расчет суммарного показателя загрязнения $(\mathrm{Zc})$ донных отложений водоемов Воронежской городской агломерации приведен в таблице 5 . Расчетные показатели для Воронежского водохранилища отличаются мозаичностью. Наиболее высокая нагрузка установлена на участке от ВОГРЭСовского моста до плотины водохранилища (район сквера Гидроузел), т.е. выше и ниже сброса с городских очистных сооружений левого берега. 


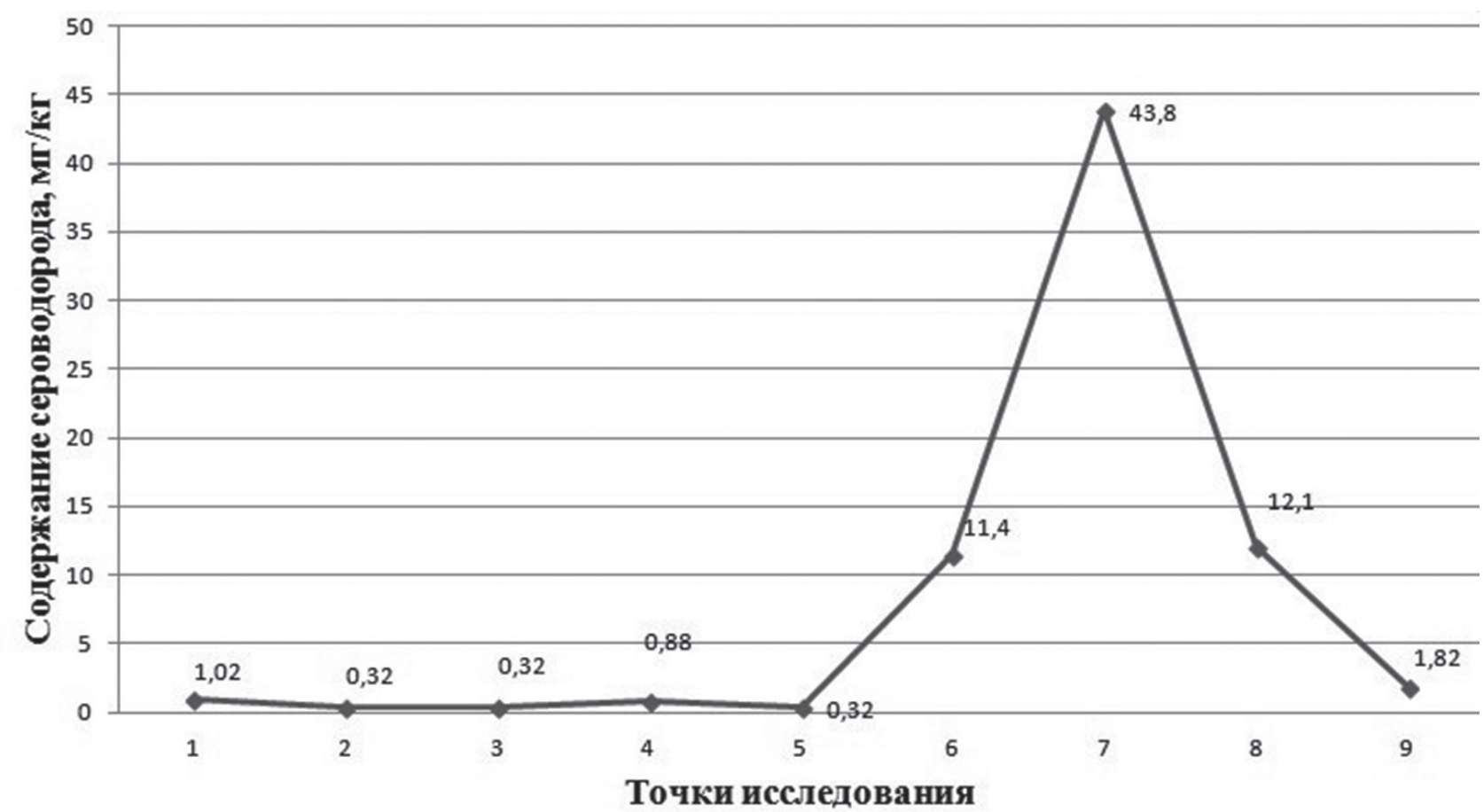

Puc. 4. Распределение сероводорода в донных отложениях Воронежского водохранилища и реки Воронеж в 2019 году

[Fig. 4. Distribution of hydrogen sulfide in the bottom sediments of the Voronezh Reservoir and the Voronezh River in 2019]

В границах водохранилища есть участки практически чистые, в которых не выявлено превышения загрязнения допустимого уровня. Территориально они расположены выше сброса ливневых и сточных вод с территории города Воронежа.

В 2020 году впервые донные отложения Воронежского водохранилища исследовались на содержания микропластика. В 10 см слое донного грунта в 500 м ниже сброса с городских очистных сооружений выделены частицы микропластика размером менее 5 мм. Частицы микропластика представлены фрагментами пленки, волокон и хлопьями различной конфигурации (рис. 5, 6, 7). Фотографии сделаны с использованием видеоокуляра DCM500 микроскопа Микмед-6 (Shangrao TeleView Optical Instruments Co., Ltd) на кафедре генетики, цитологии и биоинженерии медико-биологического факультета Воронежского государственного университета.

Таблииа 3

Суммарные показатели химического загрязнения (Zc) донных отложений

Воронежского водохранилища

[Table 3. Total indicators of chemical pollution $(\mathrm{Zc})$ of the bottom sediments in the Voronezh reservoir]

\begin{tabular}{|c|c|c|c|}
\hline $\begin{array}{c}\text { Номера } \\
\text { оочек / } \\
\text { Points No. }\end{array}$ & $\begin{array}{c}\text { Фактическое } \\
\text { значение Zc / } \\
\text { Actual value Zc }\end{array}$ & $\begin{array}{c}\text { Кратность превышения Zc } \\
\text { допустимого уровня / The multiplicity } \\
\text { of eхсеeding the permissible level Zc }\end{array}$ & $\begin{array}{c}\text { Уровень } \\
\text { загрязнения / Pollution level }\end{array}$ \\
\hline \multicolumn{5}{|c|}{ Воронежское водохранилище / Voronezh reservoir } \\
\hline 1 & 19 & Менее 2 & Средний \\
\hline 2 & 14 & Нет превышения & Низкий \\
\hline 3 & 16,3 & Менее 2 & Средниий \\
\hline 4 & 19,4 & Менее 2 & Средний \\
\hline 5 & 16,7 & Менее 2 & Высокий \\
\hline 6 & 68 & Свыше 2 & Очень высокий \\
\hline 7 & 311 & Свыше 2 & Высокий \\
\hline 8 & 51 & Свыше 2 & Высокий \\
\hline 9 & 20 & Свыше 2 & \\
\hline
\end{tabular}

Вестник ВГУ, Серия: География. Геоэкология, 2021, № 2, 70-79 


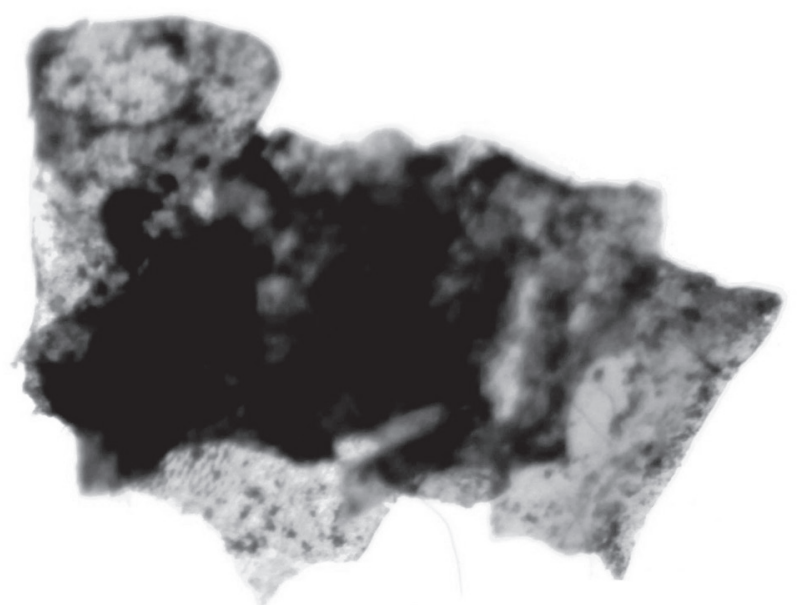

Puc. 5. Частицы микропластика размером от 2,5 до 5 мм в донных отложениях Воронежского водохранилища

[Fig. 5. Microplastic particles ranging in size from 2.5 to $5 \mathrm{~mm}$ in the bottom sediments of the Voronezh reservoir]

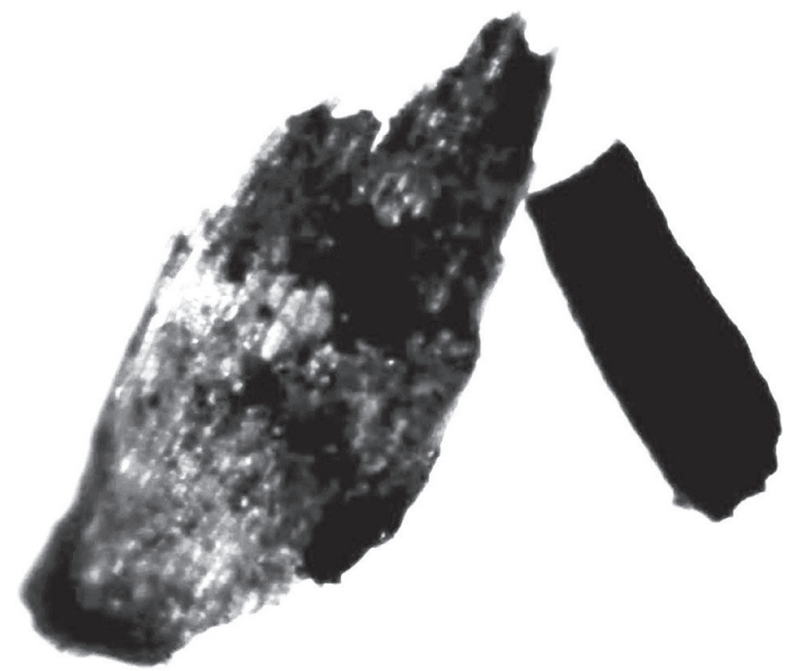

Рис. 6. Частицы микропластика размером от 0,05 до 0,1 мм в донных отложениях Воронежского водохранилища

[Fig. 6. Microplastic particles ranging in size from 0.05 to $0.1 \mathrm{~mm}$ in the bottom sediments of the Voronezh reservoir]

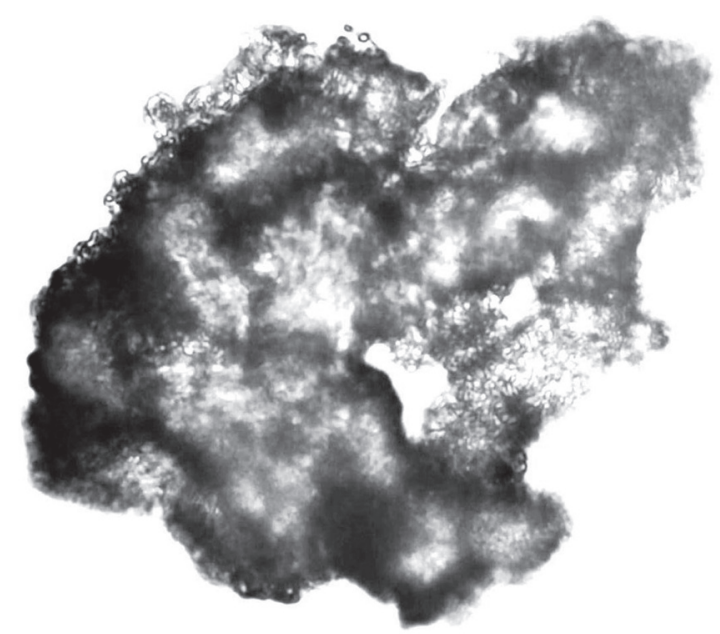

Рис. 7. Частицы микропластика размером менее 0,05 мм в донных отложениях Воронежского водохранилища

[Fig. 7. Microplastic particles less than $0.05 \mathrm{~mm}$ in size in the bottom sediments of the Voronezh reservoir]

Proceedings of VSU, Series: Geography. Geoecology, 2021, no. 2, 70-79 
Микропластик, отделенный от сопутствующих частиц просеиванием через каскад сит и размером менее 1,25 мм, был дополнительно обработан перекисью водорода (рис. 6). На глубине 10 см найдены единичные включения микропластика размером менее 0,05 мм (рис. 7 ).

\section{ЗАКЛЮЧЕНИЕ}

Современное состояние Воронежского водохранилища характеризуется высокой степенью антропогенного воздействия. Оценка сложившейся экологической ситуации в границах Воронежской городской агломерации требует дифференцированного подхода, обусловленного различным уровнем эвтрофикации водоема.

Накопление донных отложений в условиях засушливого климата может привести к разрушению экосистем водоема и появлению на территории города заболоченных участков.

Выявленное загрязнение и значительное преобладание в донном грунте песчаной фракции полностью исключает возможность его использования для повышения продуктивности сельхозугодий.

Уровни содержания тяжелых металлов в отложениях водохранилища, в первую очередь результат антропогенного воздействия. Геохимические особенности водосборных территорий - это второй по важности фактор.

Все исследованные пробы донного грунта содержали частицы микропластика. Количество накопленного микропластика в донных отложениях и его негативное воздействие на состояние экосистемы водохранилища в значительной степени недооценено. Деградированные синтетические полимеры существенно различаются размерами и присутствуют в водоеме в форме волокон, пленки и хлопьев.

\section{СПИСОК ЛИТЕРАТУРЫ}

1. Батоян В.В. Особенности геохимического профиля подводных почв в водоемах с нейтральной реакцией // Вестник Московского государственного университета. Серия 5. География, 1983, № 3, с. 79-86.

2. Доклад о состоянии окружающей среды на территории Воронежской области в 2013 году / Департамент природных ресурсов и экологии Воронежской области. Воронеж: Издательский дом ВГУ, 2014. 192 с.

3. Доклад о состоянии окружающей среды на территории Воронежской области в 2018 году / Департамент природных ресурсов и экологии Воронежской области. Воронеж: 2019. 146 с.

4. Доклад о состоянии окружающей среды на территории Воронежской области в 2019 году / Департамент природных ресурсов и экологии Воронежской области. Воронеж: 2020. 256 с.

5. Ершова Е.Ю., Веницианов Е.В., Кочярян А.Г., Вульфсон Е.К. Тяжелые металлы в донных отложениях Куйбышевского водохранилища // Водные ресурсы, 1996, № 1, c. 59-65.

6. Лукьянов С.А., Лебедев А.А., Шварцман Ю.Г. Гранулометрический состав донных отложений и его распределение в устьевой зоне $\mathrm{p}$. Северной Двины // Вестник Северного (Арктического) федерального университета, серия Естественные науки, 2011, № 2, c. 12-19.

7. Методы экологических исследований: учебное пособие для вузов [гриф ФУМО «Науки о Земле»] / Н.В. Каверина и [др.]. Воронеж: издательство «Научная книга», 2019. 355 с.

8. Прожорина Т.И., Куролап С. А., Каверина Н.В. Гидрохимия речных вод Воронежской городской агломерации // Вестник Воронежского государственного университета. Серия: География. Геоэкология, 2020, № 3, с. 78-85. DOI: https://doi.org/10.17308/ geo.2020.3/3027.

Конфликт интересов: Авторы декларируют отсутствие явных и потенциальных конфликтов интересов, связанных с публикацией настоящей статьи.

Поступила в редакиию 01.02.2021 Принята к публикаичи 28.05.2021 


\title{
THE STUDIES OF VORONEZH LOCAL LORE
}

\section{Ecological Safety of the Bottom Sediments in the Voronezh Reservoir}

\author{
N.V. Kaverina ${ }^{\square}$, S.A. Kurolap \\ Voronezh state University, Russian Federation \\ (1, Universitetskaya Pl., Voronezh, 394018)
}

\begin{abstract}
The aim of the study is to assess the bottom sediments quality in the Voronezh River basin and the Voronezh reservoir within the Voronezh Urban agglomeration.

Materials and methods. The article presents the results of chemical analysis of the state of the bottom sediments in the Voronezh reservoir and the Voronezh River (the left tributary of the Don River) in the zone of direct impact of the developed industrial centre - the city of Voronezh. The quantitative chemical analysis of pollutants in the bottom sediments was carried out on the basis of the certified Ecological and Analytical Laboratory of the Faculty of Geography, Geoecology and Tourism of Voronezh State University using potentiometric, titrimetric, voltammetric, gravimetric and granulometric methods of analysis.

Results. The current state of the Voronezh reservoir is characterized by a high degree of anthropogenic load due to developed industry and dense residential development. According to the dynamics of the spatio-temporal accumulation of pollutants in the reservoir, zones with different levels of eutrophication are distinguished.

Conclusion. The studied samples of the bottom soil contain microplastics particles of anthropogenic origin, the negative impact of which on the state of the reservoir ecosystem is largely underestimated.
\end{abstract}

Key words: bottom sediments, quantitative, analysis, qualitative analysis, concentration clark, total pollution indicator, priority pollutants, microplastics.

Funding: The study was supported by the RFBR, project no. 20-05-00779.

For citation: Kaverina N. V., Kurolap S. A. Ecological Safety of the Bottom Sediments in the Voronezh Reservoir. Vestnik Voronezskogo gosudarstvennogo universiteta. Seria: Geografia geoekologia, 2021, no. 2, pp. 70-79. (In Russ.). DOI: https://doi.org/10.17308/geo.2021.2/3450

\section{REFERENCES}

1. Batoyan V.V. Osobennosti geohimicheskogo profilya podvodnyh pochv $\mathrm{v}$ vodoemah $\mathrm{s}$ nejtralnoj reakcii [Features of the geochemical profile of underwater soils in reservoirs with a neutral reaction]. Vestnik Moskovskogo gosudarstvennogo universiteta. Seriya 5. Geografiya, 1983, no. 3, pp. 79-86. (In Russ.)

2. Doklad o sostoyanii okruzhayushchej sredy na territorii Voronezhskoj oblasti v 2013 godu [Report jn the state of environment in the Voronezh Region in 2013]. Departament prirodnyh resursov i ekologii Voronezhskoj oblasti. Voronezh, 2014. 192 p. (In Russ.)

3. Doklad o sostoyanii okruzhayushchej sredy na territorii Voronezhskoj oblasti v 2018 godu [Report jn the state of environment in the Voronezh Region in 2018]. Departament prirodnyh resursov i ekologii Voronezhskoj oblasti. Voronezh, 2019. 146 p. (In Russ.)

4. Doklad o sostoyanii okruzhayushchej sredy na territorii Voronezhskoj oblasti v 2019 godu [Report jn the state of environment in the Voronezh Region in 2020]. Departament prirodnyh resursov i ekologii Voronezhskoj oblasti. Voronezh, 2020. 256 p. (In Russ.)

5. Ershova E. Yu, Venitsianov E.V., Kochyaryan A. G., Vul'fson E.K. Tyazhelye metally $\mathrm{v}$ donnyh otlozheniyah Kujbyshevskogo vodohranilisha [Heavy metals in the bottom sediments of the Kuibyshev reservoir]. Vodnye resursy, 1996, no. 1, pp. 59-65. (In Russ.)

6. Luk'yanov S.A., Lebedev A.A., Shvartsman Yu. G. Granulometricheskij sostav donnyh otlozhenij i ego raspredelenie v ustevoj zone r. Severnoj Dviny [Granulometric composition of bottom sediments and its distribution in the estuarine zone of the Northern Dvina river] Vestnik Severnogo (Arkticheskogo) federalnogo universiteta, ser. Estestvennye nauki, 2011, no. 2, pp. 12-19. (In Russ.)

7. Kaverina N.V. [et all.] Metody ekologicheskih issledovanij: uchebnoe posobie dlya vuzov [Methods of ecological research: a training manual for higher educatijn in stitutions]. Voronezh: izdatel'stvo "Nauchnaya kniga", 2019. 355 p. (In Russ.)

(C) Kaverina N. V., Kurolap S.A., 2021

$\square$ Nataliya V. Kaverina, e-mail: knataliy@mail.ru

The content is available under Creative Commons Attribution 4.0 License. 
8. Prozhorina T.I., Kurolap S.A., Kaverina N. V. Gidrokhimiya rechnykh vod Vo-ronezhskoy gorodskoy aglomeratsii [Hydrochemistry of river water in the Voronezh urban agglomeration]. Vestnik Voronezskogo gosudarstvennogo universiteta. Geografia geoekologia, 2020, no. 3, pp. 78-85. (In Russ.) DOI: https://doi.org/10.17308/ geo.2020.3/3027.

\section{Каверина Наталия Викторовна}

кандидат географических наук, доцент кафедры геоэкологии и мониторинга окружающей среды факультета географии, геоэкологии и туризма Воронежского государственного университета, г. Воронеж, Российская Федерация, ORCID: 0000-00017085-1466, e-mail: knataliy@mail.ru

Куролап Семен Александрович

доктор географических наук, профессор, декан факультета географии, геоэкологии и туризма Воронежского государственного университета, г. Воронеж, Российская Федерация, ORCID: 0000-00026169-8014, e-mail: skurolap@mail.ru
Conflict of interests: The authors declare no information of obvious and potential conflicts of interest related to the publication of this article.

Received: 01.02.2021

Accepted: 28.05.2021

Nataliya V. Kaverina

Cand. (Geogr.) Sci., Associate Professor at the Department of Geoecology and Environmental Monitoring of the Faculty of Geography, Geoecology and Tourism, Voronezh State University, Voronezh, Russian Federation, ORCID: 0000-0001-7085-1466, e-mail: knataliy@mail.ru

Semyen A. Kurolap

Dr. (Geogr.) Sci., Professor, Dean of the Faculty of Geography, Geoecology and Tourism, the Head of the Department of Geoecology and Environmental Monitoring, Voronezh State University, Voronezh, Russian Federation, ORCID: 0000-0002-6169-8014, e-mail: skurolap@mail.ru 